\title{
(2) OPEN ACCESS \\ Gelatinous bone marrow transformation due to extensive weight loss in median arcuate ligament syndrome
}

\author{
Lorena Miguelañez Matute, ${ }^{1}$ Desiree van Noord, ${ }^{2}$ Nazik Rayman, ${ }^{1}$ Samara S Guillen ${ }^{1}$
}

${ }^{1}$ Internal Medicine, Franciscus Gasthuis en Vlietland, Rotterdam, The Netherlands ${ }^{2}$ Gastroenterology, Franciscus Gasthuis en Vlietland, Rotterdam, The Netherlands

\section{Correspondence to}

Samara S Guillen; s.guillen@franciscus.n

Accepted 7 December 2021

Check for updates

(c) BMJ Publishing Group Limited 2022. Re-use permitted under CC BY-NC. No commercial re-use. See rights and permissions. Published by BMJ.

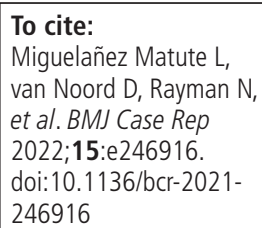

\section{SUMMARY}

A 34-year-old man was referred to the outpatient clinic because of progressive abdominal pain, weight loss and pancytopenia. His body mass index (BMI) had fallen to $14.2 \mathrm{~kg} / \mathrm{m}^{2}$. A CT angiography (CTA) showed narrowing of the truncus coeliacus with poststenotic dilation, and duodenal biopsy revealed ischaemia establishing a rare diagnosis: median arcuate ligament syndrome (MALS). This explained the postprandial pain and minimal intake. Further pancytopenia workup was performed. The bone marrow displayed gelatinous marrow transformation (GMT), a rare disorder of unknown pathogenesis, which has been associated with severe malnutrition. The final diagnosis was pancytopenia secondary to GMT due to severe malnutrition caused by MALS. The abnormalities in the bone marrow may be reversible by restoring nutritional status. This case emphasises the awareness of GMT in patients with weight loss, malnutrition and cytopenias. To our knowledge, this is the first report demonstrating an association between pancytopenia and MALS.

\section{BACKGROUND}

Malnutrition may cause pancytopenia by gelatinous marrow transformation (GMT), also known as 'starvation marrow' or 'serous fat atrophy'. 12 GMT is a rare haematological entity characterised by hypoplasia, adipose cell atrophy and deposition of a gelatinous substance in the bone marrow. ${ }^{3}$ The underlying pathophysiological mechanisms have not yet been fully elucidated. Treatment is based on treating the underlying cause and complete reversibility of GMT may be possible by restoring nutritional status. ${ }^{4}$ Although GMT has been described in several diseases and also in gastrointestinal diseases like Crohn's disease, it has not been reported in median arcuate ligament syndrome (MALS). MALS is a rare diagnosis, in which compression of the coeliac artery occurs by the median arcuate ligament, a fibrous arch that unites the diaphragmatic crura on either side of the aortic hiatus. Although compression of the coeliac artery may not always cause symptoms, individuals may suffer from postprandial abdominal pain, nausea, vomiting and fear of eating leading to significant weight loss. Several theories on the pathogenesis of MALS have been described, but the exact mechanisms remain unclear. The standard treatment is decompression of the coeliac artery by surgical intervention.

We present a case of a young man with pancytopenia secondary to GMT due to severe malnutrition caused by MALS. This case emphasises the awareness of GMT in patients presenting with weight loss, malnutrition and cytopenias. Gastrointestinal disorders may contribute to the aetiology of GMT, but since GMT is a morphological sign of an underlying disease, other causes should be ruled out before establishing a diagnosis. The recognition of GMT could help guide investigations and treatment. To our knowledge, this is the first case reporting GMT in MALS.

\section{CASE PRESENTATION}

A 34-year-old man was referred to the outpatient clinic because of abdominal pain, weight loss and pancytopenia. His medical history included a traumatic kidney laceration and wound cellulitis.

$\mathrm{He}$ has been suffering from nausea and progressive postprandial abdominal pain. This led to a fear of eating and thus, weight loss. His stool was looser than normal. He also complained of fatigue and lightheadedness. There was no history of recurrent infections.

On physical examination we observed a cachectic man weighing $41 \mathrm{~kg}$ (BMI 14.19). His parotid glands were visible, and he had lip bruises and sores in the mouth. The palms of his hands were dark. He had a blood pressure of $100 / 50 \mathrm{~mm} \mathrm{Hg}$ with a normal pulse. Abdominal examination was unremarkable.

\section{INVESTIGATIONS}

Before visiting the outpatient clinic, laboratory tests were drawn and an abdominal ultrasound was made. Laboratory tests showed a pancytopenia (table 1). Abdominal ultrasound showed a normal aspect of the abdominal organs, but also faecal impaction of the colon without small bowel distension and a small amount of free intraperitoneal fluid. Para-aortal lymph nodes appeared normal. Given concerns for a malignancy or severe infection, a CT scan was obtained immediately which showed no abnormalities except faecal impaction of the colon. There were no signs of lymphadenopathy or hepatosplenomegaly. A normal positron emission tomography (PET)-CT ruled out an infection and confirmed that there was no malignancy.

A colonoscopy ruled out colorectal cancer and inflammatory bowel disease. A gastroscopy showed pale mucosa of the duodenal bulb and multiple erosions in the antrum. Duodenal biopsy revealed ischaemia of the duodenum. 


\begin{tabular}{|c|c|c|}
\hline Investigation & Outcome & Reference \\
\hline \multicolumn{3}{|l|}{ Chemistry } \\
\hline CRP & $<1$ & $0-5 \mathrm{mg} / \mathrm{L}$ \\
\hline LD & 166 & $<248 \mathrm{U} / \mathrm{L}$ \\
\hline TSH & 1.19 & $0.35-4.94 \mathrm{mlU} / \mathrm{L}$ \\
\hline ACTH & 39 & $63 \mathrm{ng} / \mathrm{L}$ \\
\hline Cortisol & 588 & $101-536 \mathrm{nmol} / \mathrm{L}$ \\
\hline ESR & 2 & $<15 \mathrm{~mm} /$ hour \\
\hline Haemoglobin & 8.2 & $8.5-11.0 \mathrm{mmol} / \mathrm{L}$ \\
\hline Erythrocytes & 4.1 & $4.5-5.5 \times 10^{12} / \mathrm{L}$ \\
\hline MCV & 97 & $80-100 \mathrm{fL}$ \\
\hline RDW & 11.5 & $12.3 \%-14.3 \%$ \\
\hline Thrombocytes & 132 & $150-400 \times 10^{9} / \mathrm{L}$ \\
\hline Reticulocytes & 0.014 & $0.025-0.120 \times 10^{12} / \mathrm{L}$ \\
\hline Leucocytes & 1.6 & $4.0-10.0 \times 10^{9} / \mathrm{L}$ \\
\hline Neutrophils & 1.0 & $2.0-7.5 \times 10^{9} / \mathrm{L}$ \\
\hline Lymphocytes & 0.4 & $1.0-3.5 \times 10^{9} / \mathrm{L}$ \\
\hline Monocytes & 0.2 & $0.3-1.0 \times 10^{9} / \mathrm{L}$ \\
\hline \multicolumn{3}{|l|}{ Transaminases } \\
\hline ALAT & 39 & $0-45 \mathrm{U} / \mathrm{L}$ \\
\hline ASAT & 25 & $0-35 \mathrm{U} / \mathrm{L}$ \\
\hline Gamma-GT & 16 & $0-40 \mathrm{U} / \mathrm{L}$ \\
\hline Alkaline phosphatase & 67 & $0-125 \mathrm{U} / \mathrm{L}$ \\
\hline Bilirubin & 4.0 & $3.4-20.8 \mu \mathrm{mol} / \mathrm{L}$ \\
\hline Haptoglobin & 0.50 & $0.14-2.58 \mathrm{~g} / \mathrm{L}$ \\
\hline Lipase & 28 & $8-78 \mathrm{U} / \mathrm{L}$ \\
\hline Albumin & 47 & $35-52 \mathrm{~g} / \mathrm{L}$ \\
\hline Ferritin & 146 & $22-275 \mu \mathrm{g} / \mathrm{L}$ \\
\hline Vitamin $B_{12}$ & $>128$ & $>32 \mathrm{pmol} / \mathrm{L}$ \\
\hline Folic acid & 12.1 & $7.0-46.4 \mathrm{nmol} / \mathrm{L}$ \\
\hline Copper & 12 & $10-24 \mu \mathrm{mol} / \mathrm{L}$ \\
\hline Zinc & 14.5 & $9.4-20.6 \mu \mathrm{mol} / \mathrm{L}$ \\
\hline \multicolumn{3}{|l|}{ Immunology } \\
\hline $\lg G$ & 8.8 & $7.0-16.0 \mathrm{~g} / \mathrm{L}$ \\
\hline $\lg A$ & 1.3 & $0.70-4.00 \mathrm{~g} / \mathrm{L}$ \\
\hline $\lg M$ & 0.6 & $0.2-2.4 \mathrm{~g} / \mathrm{L}$ \\
\hline Anti-tTG as (IgA) & 0.2 & $<7 \mathrm{U} / \mathrm{mL}$ \\
\hline \multicolumn{3}{|l|}{ Microbiology } \\
\hline \multicolumn{3}{|l|}{ Virus serology } \\
\hline CMV IgM, CMV IgG & Negative & Negative \\
\hline $\begin{array}{l}\text { EBV ERNA-lgG, EBV VCA-IgG, EBV } \\
\text { VCA-lgM }\end{array}$ & Negative & Negative \\
\hline $\begin{array}{l}\text { Parvovirus B19 lgG, Parvovirus } \\
\text { B19 lgM }\end{array}$ & Negative & Negative \\
\hline HIV & Negative & Negative \\
\hline Lues & Negative & Negative \\
\hline T-spot & Negative & Negative \\
\hline
\end{tabular}

Bolded values represent abnormal values.

ACTH, adrenocorticotropic hormone; ALAT, alanine aminotransferase; Anti-tTG, antibodies to tissue transglutaminase; ASAT, aspartate transaminase; CMV, cytomegalovirus; CRP, C reactive protein; EBV, Epstein-Barr virus; ESR, erythrocyte sedimentation rate; Gamma-GT, gamma-glutamyltransferase; HIV, human immunodeficiency virus; IgA, immunoglobulin A; IgG, immunoglobulin $\mathrm{G}$; IgM, immunoglobulin $\mathrm{M}$; $L D$, lactate dehydrogenase; MCV, mean corpuscular volume; RDW, red blood cell distribution width; TSH, thyroid stimulating hormone; VCA, virus capsid antigen.

Because of the hypotension and darkened hand palms a synacthen test was performed to rule out Addison's disease. The CT angiography revealed 70\% narrowing of the truncus celiacus with poststenotic dilation, a radiological feature of MALS (figure 1). This explained the abdominal pain and weight loss, which are characteristic symptoms of MALS, but the pancytopenia remained unexplained. We continued with the evaluation of pancytopenia. Viral causes were excluded (table 1) and T-spot was negative. Bone marrow biopsy revealed extensive

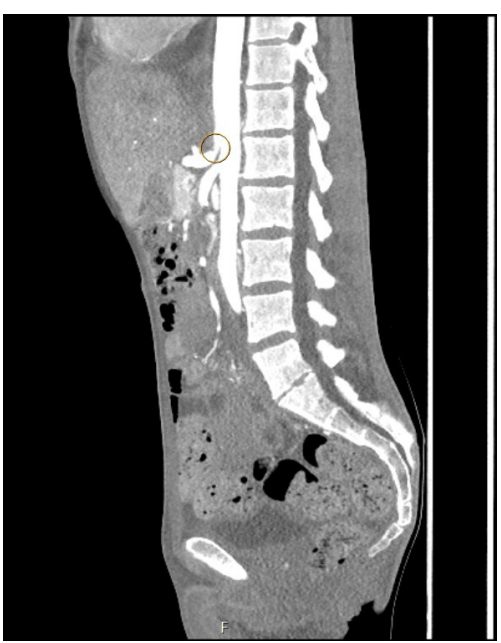

Figure 1 Sagittal view of CT angiography in patient with median arcuate ligament syndrome demonstrating narrowing of the truncus celiacus with poststenotic dilation.

degenerative changes of the bone marrow and fat marrow. This established the diagnosis GMT (figure 2). There were no signs of aplastic anaemia or myelodysplastic disorder. Immunophenotyping showed aberrant T-cell population, and T-cell receptor gene rearrangement showed polyclonal T-cel population. Chromosome analysis showed a normal karyotype of the bone marrow.

\section{TREATMENT}

The patient was discussed in a multidisciplinary expert panel setting and they advised to improve the patient's nutritional status before undergoing surgical release for MALS.

\section{OUTCOME AND FOLLOW-UP}

After the patient was discussed in the multidisciplinary expert panel setting, hospitalisation was advised to start the feeding process. Unfortunately he opted not to be admitted and wanted

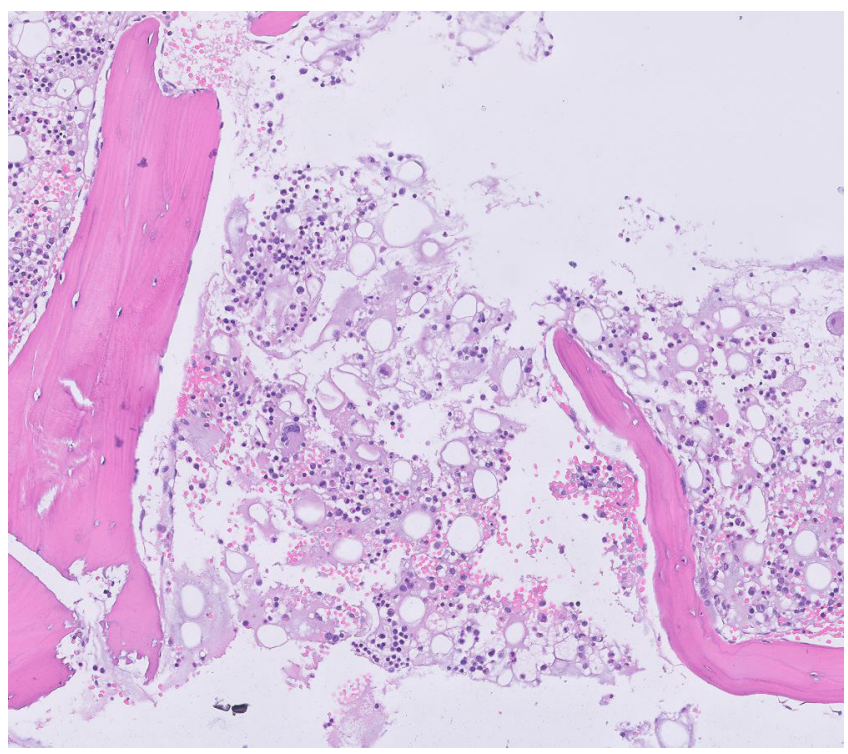

Figure 2 Bone marrow showing gelatinous transformation combining haematopoietic hypoplasia, adipose cell atrophy and deposition of gelatinous substance (low magnification, 100x; H\&E stain). 
to try gaining weight on his own. Nevertheless he remained in a severe cachectic state and the pancytopenia persisted. Gastric infarction and perforation were considered as possible complications of MALS. However, he preferred to continue improving nutritional intake by himself and refused further treatment.

\section{DISCUSSION}

We described a case of a young man presenting with postprandial pain, weight loss and pancytopenia establishing two rare diagnosis: MALS and GMT. MALS has been recognised as the most common cause of single-vessel arterial stenosis. ${ }^{5}$ Patients may adapt their eating pattern to avoid postprandial pain and in severe cases this can lead to food avoidance causing malnutrition and severe weight loss. In a retrospective study $40 \%$ of the individuals reported weight loss. ${ }^{6}$ The exact incidence of MALS is unknown and most studies report incidences of asymptomatic MALS as accidental findings ranging from $3.4 \%$ to $7.3 \% .^{78}$ The prevalence is higher in young women and in individuals with a low BMI. ${ }^{9}$ There is a lack of standard diagnostic criteria, but since the severity of truncus celiacus narrowing is influenced by respiration, imaging must always be performed at maximal inspiration and expiration. Alternative diagnosis needs to be excluded before the diagnosis MALS may be established. Furthermore, there is no consensus on management. A systematic review including data from 400 patients reported postoperative relief in $85 \% .{ }^{10}$ However, data on long-term effect is lacking. Surgical intervention might be considered after assessment through a multidisciplinary expert panel setting.

GMT is a haematological entity associated with numerous aetiologies and is a marker for underlying disease. Therefore, GMT is not a specific disease of the bone marrow and other causes should be ruled out before establishing a diagnosis. Since GMT has been associated with eating disorders such as anorexia nervosa and self-induced starvation, the severe malnutrition was highly likely to be the underlying cause of the pancytopenia. Nevertheless, other causes were ruled out. At first, malignancy was suspected since the CT showed faecal impaction and wall thickening of the colon. Colonoscopy showed no abnormalities and also ruled out Crohn's disease. Other gastrointestinal diseases such as coeliac disease and gastric ulcer were ruled out by gastroscopy. A malignancy, including haematological malignancy, was ruled out by immunophenotyping, normal karyotype of the bone marrow and no abnormalities seen on the CT scan and PET-CT. Infectious diseases were unlikely, since infection parameters were low and viral serology was negative. T-spot for tuberculosis was negative, making tuberculosis unlikely. In addition, PET-CT revealed no sources of infection. The patient had no history of alcohol abuse, and there were no signs of metabolic or autoimmune disorders. In conclusion, the diagnosis GMT due to severe malnutrition in MALS was made.

The incidence of GMT varies in literature, and an increased number of case reports has been seen in the last two decades suggesting an increase in awareness. In a retrospective study 80 000 bone marrow biopsies were revised and revealed a GMT incidence of $0.2 \% \pm 0.08 \%$ in all age groups. There was a peak incidence of $0.5 \%$ in the age group of 20-29 years old. GMT occurred more often in men, and more severe forms were seen in younger patients. Nevertheless, higher incidences in smaller Indian studies are described. Sen et al reported an incidence of $4.39 \% .{ }^{11}$ The lack of awareness about the existence of GMT may have led to lower incidence.

In anorexia nervosa malnutrition is mostly based on a depletion of protein and fat. Wang et al and Rafiullah et al described
GMT in a patient on a starch-free diet and a case with unusual eating habits and weight loss, respectively. ${ }^{12} 13$ The amount of weight loss is correlated to the extent of damage in the bone marrow and may be the predominant risk factor. ${ }^{14}$ The presenting haematological laboratory parameter in the majority of cases with GMT is the presence of at least one peripheral cytopenia, mostly anaemia. In Böhm et al $82 \%$ of the patients had anaemia. However, the degree of anaemia, total leucocyte and platelet blood counts, did not correlate with the extent of GMT. ${ }^{4}$ In Jane et $a l^{11}$ all patients had moderate to severe anaemia. Pancytopenia, as the initial presentation, has also been described, however less often. ${ }^{15}$

The pathophysiology of GMT needs still to be elucidated; however, the mechanism of malnutrition leading to GMT may be explained by excessive production of mucopolysaccharide of ground substance to compensate for the mobilisation of marrow fat due to severe catabolism. ${ }^{16}$ Nevertheless, additional factors are likely to be involved since not every patient with malnutrition develops GMT. Moreover, not all cases of GMT are associated with weight loss. ${ }^{3}$ In several case reports reversibility of GMT has been described after improvement of nutritional state. ${ }^{12} 1317$ This may be explained by the occurrence of limited cell necrosis as cellularity in the marrow also decreases due to lack of growth factors secondary to starvation. ${ }^{18}$

This case describes how a gastrointestinal disorder may become an aetiological factor in the causation of pancytopenia and bone marrow abnormalities. The association of haematological abnormalities in patients with MALS have not been reported before, probably because MALS is uncommon and differs in severity. It is important to be aware of morphological changes in bone marrow in patients presenting with malnutrition, weight loss and cytopenias. Raising awareness of GMT and MALS may contribute to avoid diagnostic delays, underdiagnosis and undertreatment. To our knowledge, this is the first report describing pancytopenia and GMT in a patient with MALS.

\section{Learning points}

- Pancytopenia may be caused by gelatinous marrow transformation (GMT), a rare morphological sign of a generalised illness or condition including severe malnutrition. This may be a reversible process if nutritional status improves.

- Median arcuate ligament syndrome (MALS) is an underdiagnosed disease causing postprandial pain, food avoidance and weight loss.

- Pancytopenia may be the revealing feature of MALS and physicians should be aware of GMT in cachectic patients due to underlying gastroenterology diseases

- Lack of suspicion of GMT and MALS can lead to diagnostic delays, underdiagnosis and undertreatment.

Contributors LMM: writing the manuscript. DvN: critically reviewed the manuscript. NR: critically reviewed the manuscript. SSG: provided the patient and conceived the idea for writing the case report, critically reviewed the manuscript.

Funding The authors have not declared a specific grant for this research from any funding agency in the public, commercial or not-for-profit sectors.

Competing interests None declared.

Patient consent for publication Consent obtained directly from patient(s).

Provenance and peer review Not commissioned; externally peer reviewed.

Open access This is an open access article distributed in accordance with the Creative Commons Attribution Non Commercial (CC BY-NC 4.0) license, which permits others to distribute, remix, adapt, build upon this work non-commercially, and license their derivative works on different terms, provided the original work 
is properly cited and the use is non-commercial. See: http://creativecommons.org/ licenses/by-nc/4.0/.

Case reports provide a valuable learning resource for the scientific community and can indicate areas of interest for future research. They should not be used in isolation to guide treatment choices or public health policy.

\section{REFERENCES}

1 Clarke BE, Brown DJ, Xipell JM. Gelatinous transformation of the bone marrow. Pathology 1983;15:85-8.

2 Seaman JP, Kjeldsberg CR, Linker A. Gelatinous transformation of the bone marrow. Hum Pathol 1978;9:685-92.

3 Böhm J. Gelatinous transformation of the bone marrow: the spectrum of underlying diseases. Am J Surg Pathol 2000;24:56-65.

4 Shergill KK, Shergill GS, Pillai HJ. Gelatinous transformation of bone marrow: rare or underdiagnosed? Autops Case Rep 2017;7:8-17.

5 Björck M, Koelemay M, Acosta S, et al. Editor's Choice - Management of the Diseases of Mesenteric Arteries and Veins: Clinical Practice Guidelines of the European Society of Vascular Surgery (ESVS). Eur J Vasc Endovasc Surg 2017:53:460-510.

6 Ho KKF, Walker P, Smithers BM, et al. Outcome predictors in median arcuate ligament syndrome. J Vasc Surg 2017:65:1745-52.

7 Park CM, Chung JW, Kim HB, et al. Celiac axis stenosis: incidence and etiologies in asymptomatic individuals. Korean J Radiol 2001;2:8-13.
8 Petnys A, Puech-Leão P, Zerati AE, et al. Prevalence of signs of celiac axis compression by the median arcuate ligament on computed tomography angiography in asymptomatic patients. J Vasc Surg 2018;68:1782-7.

9 Kim EN, Lamb K, Relles D, et al. Median arcuate ligament Syndrome-Review of this rare disease. JAMA Surg 2016;151:471-7.

10 Jimenez JC, Harlander-Locke M, Dutson EP. Open and laparoscopic treatment of median arcuate ligament syndrome. J Vasc Surg 2012;56:869-73.

11 Jain R, Singh ZN, Khurana N, et al. Gelatinous transformation of bone marrow: a study of 43 cases. Indian J Pathol Microbiol 2005;48:1-3.

12 Wang C, Amato D, Fernandes B. Gelatinous transformation of bone marrow from a starch-free diet. Am J Hematol 2001:68:58-9.

13 Islam R, Mahmood R, Sitwala KV. Gelatinous bone marrow transformation secondary to unusual eating habits and drastic weight loss. BMJ Case Rep 2013;2013. doi:10.1136/bcr-2013-200243. [Epub ahead of print: 16 Jul 2013].

14 Abella E, Feliu E, Granada I, et al. Bone marrow changes in anorexia nervosa are correlated with the amount of weight loss and not with other clinical findings. Am J Clin Pathol 2002:118:582-8.

15 Das S, Mishra P, Kar R, et al. Gelatinous marrow transformation: a series of 11 cases from a tertiary care centre in South India. Turk J Haematol 2014:31:175-9.

16 Tavassoli M. Differential response of bone marrow and extramedullary adipose cells to starvation. Experientia 1974;30:424-5.

17 Osgood E, Muddassir S, Jaju M, et al. Starvation marrow - gelatinous transformation of bone marrow. J Community Hosp Intern Med Perspect 2014;4. doi:10.3402/jchimp. v4.24811. [Epub ahead of print: 29 Sep 2014].

18 Smith RR, Spivak JL. Marrow cell necrosis in anorexia nervosa and involuntary starvation. Br J Haematol 1985:60:525-30.

Copyright 2021 BMJ Publishing Group. All rights reserved. For permission to reuse any of this content visit https://www.bmj.com/company/products-services/rights-and-licensing/permissions/

BMJ Case Report Fellows may re-use this article for personal use and teaching without any further permission.

Become a Fellow of BMJ Case Reports today and you can:

- Submit as many cases as you like

- Enjoy fast sympathetic peer review and rapid publication of accepted articles

- Access all the published articles

Re-use any of the published material for personal use and teaching without further permission

Customer Service

If you have any further queries about your subscription, please contact our customer services team on +44 (0) 2071111105 or via email at support@bmj.com.

Visit casereports.bmj.com for more articles like this and to become a Fellow 